Bilecik Şeyh Edebali Üniversitesi Sosyal Bilimler Dergisi - Bilecik Şeyh Edebali University Journal of Social Sciences

ISSN/E-ISSN: 2548-088X

DOI: $10.33905 /$ bseusbed.726432

Corresponding Author/Sorumlu Yazar:

Muzaffer AYDEMIR, Altınbaş Üniversitesi, Uygulamalı Bilimler Fakültesi, Yönetim Bilişim Sistemleri Bölümü, muzaffer.aydemir@altinbas.edu.tr
Submitted/Başvuru: 27.04.2020

Accepted/Kabul: 08.06.2020

Citation/Atıf: AYDEMIR, M. (2020 Türk İşletme Tarihi ve Yönetim Bilimi Açısından Birinci İzmir İktisat Kongresi: Banka Merkezli İşletme Gruplarının Oluşumu. Bilecik Şeyh Edebali Üniversitesi Sosyal Bilimler Dergisi, 5/1, 194-213. DOI: $10.33905 /$ bseusbed.726432

\title{
Türk İșletme Tarihi ve Yönetim Bilimi Açısından Birinci İzmir İktisat Kongresi: Banka Merkezli İşletme Gruplarının Oluşumu
}

\section{The First Izmir Economic Congress In Turkish Busmess History And Management Science: The Formation Of Bank-Centred Business Groups}

\author{
Muzaffer AYDEMIR ${ }^{1}$
}

\section{$\ddot{O} z$}

Yönetim bilimi çalışmalarında Türk işletme tarihine olan ilgi giderek artmaktadır. Erken Cumhuriyet Dönemi ve öncesi, işletme tarihi çalışmaları için özellikli bir zaman dilimidir. Kazanılanbağımsızlık zaferi sonrası henüz barış anlaşması imzalanmadan ve yeni yönetim şekli ilan edilmeden düzenlenen Birinci İzmir İktisat Kongresi, tarih ve iktisat bilim insanlarınca detaylı bir şekilde ele alınmasına rağmen yönetim bilim insanları tarafından yeterince incelenmemiştir. Kurtuluş Savaşını kazanan lider kadro, sahip oldukları stratejik yönetim yetenekleri ile ülkenin milli kalkınmasını gerçekleştirebilecek örgütsel yapılar kurmuşlardır. Lider kadronun yönetiminde yapılan kongrede alınan kararlar sonucunda, Türk işletme gruplarının ilk örnekleri olan İş Bankası ve Sanayi ve Maadin Bankası kurulmuştur. Birinci İzmir İktisat Kongresi'nde benimsenen milli kalkınma amacını gerçekleştirebilmek için dönemin koşullarına bağlı olarak ortaya çıkan banka merkezli işletme grupları, daha sonra kurulacak çok sayıdaki örgütsel yapıya örnek teşkil etmiştir. Dönemin kurumsal koşullarının şekillendirdiği örgütsel yapıların analizinde kullanılan metot tarihsel dönüşüm metodolojisidir. Çalışmada, Erken Cumhuriyet döneminde kurulan özgün örgütsel yapılar tarihsel dönüşüm metodolojisi çerçevesinde ele alınarak henüz yeterince incelenmemiş döneme ışık tutulacaktır. Böyleceyönetim bilimi yazınına da katkıda bulunulacaktır.

Anahtar Kelimeler: İşletme Tarihi, İşletme Grubu, Yönetim.

\begin{abstract}
The Turkish business history has been gradually taken attraction from the management science studies. Pre and early Republican era is a specific time period for business history studies. The First Izmir Economic Congress, which was held after the War of Independence but before signing a peace treaty and declaring a new form of government, was examined in detail by the history and economics scholars; however, it has not been studied by the management scientists. The top cadre that won the War of Independence established organizational structures that can carry out the national development of the country with their strategic management skills. As a result of the decisions taken in the congress, İşbank and Sanayi and Maadin Bank were established as the first examples of Turkish business groups. Bankcentred business groups, which emerged in the first Izmir Economic Congress to meet the goal of national development, have set an example for many organizational structures that were to be established later. Theme thousand in the analysis of organizational structures shaped by the institutional conditions of the era is the historical transformation methodology. Our study will contribute to the management science by examining the original organizational structures established in the early Republican period with the historical transformation methodology and shed light on this period which has not been sufficiently examined.
\end{abstract}

Keywords: Business History, BusinesGroups, Management.

\footnotetext{
${ }^{1}$ Dr. Öğr. Üyesi, Altınbaş Üniversitesi, Uygulamalı Bilimler Fakültesi, Yönetim Bilişim Sistemleri Bölümü, muzaffer.aydemir@altinbas.edu.tr
} 


\section{Muzaffer AYDEMIR}

\section{Giriş}

Türk işletme tarihinde önemli değişikliklerin yaşandığı dönemlerden birisi Erken Cumhuriyet dönemidir. Erken Cumhuriyet dönemi, yaşanan hızlı değişimler ve ortaya çıkan özgün ve stratejik önemdeki örgütsel yapılar ile dikkat çekmektedir. Ülkenin geleceğini belirleyecek önemli stratejik kararlar Cumhuriyetin ilanından hemen önce ve sonraki dönemde alınmıştır. Hayati önem taşıyan uzun vadeli kararlar ancak yetenekli ve güçlü yöneticiler tarafından alınmaktadır (Aydemir, 2019a: 27). Stratejik yöneticiler başarılı olabilmeleri için gerekli yönetsel becerilere sahip olmalıdır. Yöneticiler, daha uzun dönem bakış açısına sahip olmalı ve meydana gelebilecek olaylara hazır olmalıdırlar (Gottschalk, 2007: 123). Mesleki yaşamlarının çoğunu başarı için zorlu stratejik kararların alındığı muharebe alanlarında geçiren yöneticiler, Erken Cumhuriyet döneminde aldıkları kararlarla, ülkenin uzun süreli geleceğini belirlemiştir.

Ülke yöneticilerinin Kurtuluş Savaşı sonrası aldıkların ilk stratejik karar Birinci İzmir İktisat Kongresi'nin toplanmasıdır. Birinci İzmir İktisat Kongresi sadece iktisat konularının görüşüldüğü bir toplantı değil, milli kalkınmayı sağlayacak örgütsel yapıların esasları belirlendiği bir girişimdir. $\mathrm{Bu}$ kapsamda, Birinci İzmir İktisat Kongresi ülkenin ekonomik geleceğini belirleyen kararların alındığı stratejik bir girişim, faaliyettir.

Stratejik önemde olan Birinci İzmir İktisat Kongresi'ne ait birçok araştırma yapılmıştır. Kongre, tarih ve iktisat bilim insanları tarafindan detaylı bir şekilde incelenmiştir. 1920'lerin ekonomik politikasında önem taşıyan gelişme Cumhuriyetin ilanından önce düzenlenen İzmir İktisat Kongresi'dir (Tuna, 2009: 20). Cumhuriyet ekonomisinin miladı İzmir İktisat Kongresi'dir (Durmuş ve Aydemir, 2016: 157). Tarihsel ve iktisadi öneminin yanında Birinci İzmir İktisat Kongresi gelecekte kurulacak olan girişimlerin, örgütsel yapıların esaslarının belirlendiği stratejik bir toplantıdır. Birinci İzmir İktisat Kongresi işletme bilimi esasları ile yeterince ele alınmamıştır. Bu kapsamda Birinci İzmir İktisat Kongresi işletme, yönetim bilimi insanları tarafından metodolojik olarak incelenmelidir.

Kongre, öncelikle farklı grupların temsilcileri tarafından kendi çalışma alanlarına ilişkin sorunların ortaya konup tartışılması, çözüm önerilerinin ortaya konması ve kararların alınmasını sağlamıştır. İzmir'de toplanan Türkiye İktisat Kongresi'nin toplanma amacı, savaştan yorgun çıkan iktisadi aktörlerin ve birimlerin birbirlerini tanımalarını sağlamak, onların ihtiyaçlarını tespit etmek, iktisadi konular üzerine dikkatleri çekmek ve iktisat politikalarını da bu sonuçlara göre belirleme isteğidir (Koçtürk ve Gölalan, 2010: 50).

Birinci İzmir İktisat Kongresi, “17 Şubat - 04 Mart” 1923 tarihinde toplanmıştır. Kongrenin tarih tesadüfen seçilmemiştir. Kongre, zafer sonrası çeşitli siyasi olayların yaşandı̆̆ı dönemde yapılmıştır. Kongrenin, Cumhuriyetin ilanından sekiz ay kadar önce ve Lozan Barış görüşmelerinin 
Türk İşletme Tarihi ve Yönetim Bilimi Açısından Birinci İzmir iktisat Kongresi:

Banka Merkezli İşletme Gruplarının Oluşumu

özellikle ekonomik konulardaki anlaşmazlıklar nedeniyle kesildiği dönemde (Koç, 2020: 155) yapılması zamanlamasının tesadüf olmadığını göstermektedir.

Kurtuluş savaşı kazanıldıktan sonra ülke hızlı bir değişim geçirmiştir. Zafer sonrası değişen koşullara bağlı olarak kısa sürede birçok yeni işletme, örgütsel yapı ortaya çıkmıştır. Yeni işletmelerin ortaya çıkışları zamana ve koşullar bağlı olarak değişmektedir. Yeni işletmelerin ortaya çıkışlarının nedenlerini bulamamızda kullanılabilecek yönetsel yaklaşım tarihsel dönüşüm metodolojisidir. Gelişme sürecine ilişkin kuramsal analiz ile tarihsel araştırma bir tarihsel dönüşüm metodolojisi aracılığıyla (Lazonick, 2007: 53) açılanabilir. Tarihsel dönüşüm metodolojisinde, yenilikçi işletmelerin ortaya çıkışları toplumsal, kurumsal koşullara bağlıdır. Ortaya çıkan yeni işletmeler dönemin koşulların bir yansımasıdır.

Birinci İzmir İktisat Kongresi’nde alınan kararlar doğrultusunda iki önemli örgütsel yapı kurulmuştur; İş Bankası ile Sanayi ve Maadin Bankası. Banka merkezli işletme grubu olarak kurulan ve daha sonra kurulacak olan birçok yeni işletmeye model oluşturan bankaların esasları Birinci İzmir İktisat Kongresi'nde belirlenmiştir. Her iki banka da dönemin kurumsal koşullarına bağlı olarak birçok işlevi yerine getirebilecek özgün bir örgütsel yapıda kurulmuştur. Banka merkezli işletme gruplarının örgütsel yapısında farklı sektörlerde faaliyet gösteren birçok işletme, iştirak bulunmaktadır. Kuruluş sözleşme ve kanununda da ifade edildiği gibi iki banka da milli kalkınmayı gerçekleştirebilmek için ihtiyaç duyulan tüm fonksiyonları tek bir örgütsel yapıda altında toplamış ve yürütmüştür.

Yapılan çalışmalarda İş Bankası ve Sanayi ve Maadin Bankaları birer sanayi grubu olarak nitelendirilmiş ancak bu yaklaşım yönetim bilimi esasları ile açıklanmamıştır. Yaşer (1973), İş Bankası'nı “İş Bankası Grubu” olarak nitelendirmiş, Zarakolu da (1974), Sanayi ve Maadin Bankası'nın bir sanayi holding şirketi gibi çalıştı̆̆ını belirtmiştir. Müteakiben yönetim bilimi esasları ile yapılan çalışmalarda da_Sanayi ve Maadin Bankası (Aydemir, Özkaleli ve Katırcıoğlu, 2012) ve İş Bankası (Aydemir, 2019b) banka merkezli işletme grubu olarak tanımlanmıştır. Ancak banka merkezli işletme grubu modelininilk esaslarının belirlendiği tarihsel kaynak henüz incelenmiştir.

Birinci İzmir İktisat Kongresi, iktisat ve tarih incelemelerinin ötesinde, işletme tarihi açısından da önemli anlam ve tespitler içermektedir. Geleceğin işletmelerinin özgün örgütsel yapıları kongrede alınan kararlar çerçevesinde şekillenmiştir. Çalışmamızda cevabı aranan soru, Cumhuriyetin ilanından sonra kurulan banka merkezli işletme grubu modelinin esaslarının hangi tarihsel süreçte ortaya çıktığıdır?

Birinci İzmir İktisat Kongresi işletme tarihi çalışmaları için önemlidir. Cumhuriyetin kuruluşu sonras1 kurulan özgün örgütsel yapılar kongrede alınan stratejik kararlar sonrası kurulmuştur. Çalışmayı yapmaktaki amacımız, Erken Cumhuriyet döneminde kurulan banka merkezli işletme gruplarının modelinin esaslarının belirlendiği Birinci İzmir İktisat Kongresi'ni yönetim bilimi esasları ile inceleyerek Türk İşletme Tarihi çalışmalarına katkıda bulunmaktır. 


\section{Muzaffer AYDEMIR}

\section{1. İzmir İktisat Kongresi}

Birinci İzmir İktisat Kongresi’ni toplayan lider kadro, kongre öncesi süreçte sadece savaşa odaklanmamış, hayatın devamını sağlayacak örgütsel yapıları da kurmuştur. Kurtuluş savaşı sürerken, Türkiye Büyük Millet Meclisi'nin 2 Mayıs I920'de hükümetin kurulması ile ilgili 3 numaralı kanunu kabul etmesi sonundaon bir bakanlıktan birisi olanİktisat (ekonomi) Bakanlığı (İnan, 1989: 12) kurulmuştur. Savaş esnasında üretim düşük seviyelerde seyretmiş, toplumun çoğu tüketici (İnan, 1989: 12) olarak kalmıştır. Savaş sonuçlandıktan ve zafer kazanıldıktan sonra kurumsal ortam son derece olumsuzdur. Ülkenin üretiminin çoğunluğunu sağlayan yerler harap olmuş, işgalin olumsuz sonuçları her alanda kendini hissettirmiştir. Kazanılan askeri zafer aslında çok daha zor yeni bir dönemin başlangıcı olmuştur. Savaş esnasında bile ekonomiye yönelik kurumları teşkil eden yönetici kadro, zafer sonrası olumsuz koşulları ortadan kaldırmak, milli kalkınmayı gerçekleştirmek için yapılacakgirişimlerin, kurulacak örgütsel yapıların esaslarını belirlemek için çabalara girişmiştir. Bu kapsamda zafer sonrası yapılan ilk önemli girişim olan Birinci İzmir İktisat Kongresi'dir. Birinci İzmir İktisat Kongresi Türk İşletme Tarihi açısından ayrıcalıkla bir yere sahiptir.

Öncelikle kongrenin düzenlendiği yer önem arz etmektedir. Anadolu'nun işgalinin başladığı ve işgali kesin olarak sonlandıracak zaferin kazanıldığı yerin seçilmesi tesadüf değildir. Ayrıca işgal ordularının kaçarken bıraktıkları harap İzmir şehri yeni ekonomik zaferlerin başarı tohumlarının atıldığı yer olacaktır. Kongre ile savaşlardan yorgun çıkan halka, ekonomik yön vermek ve harap olan yurdu kalkındırma ve mamur etme (İnan, 1989: 12) mesajlarının İzmir'den verilmesi anlamlıdır.

Kongrenin dikkat çekici özelliklerinden birisi düzenlenme zamanıdır. Birinci İzmir İktisat Kongresi 17 Şubat 1923 tarihinde başlamış ve 4 Mart 1923 tarihine kadar sürmüştür. Kongre tarihi birkaç bakımdan önemlidir. Birincisi, kongre düzenlenirken yaşanan siyasal olaylar ve bunların ekonomik yansımalarıdır. Kongre başladığında savaş yeni bitmiş, barış anlaşması henüz imzalanmamıştır. Kongrenin başladığı dönem, barış anlaşması görüşmelerin sürdüğü, ancak çeşitli kesintilerin yaşandığı bir dönemdir. Lozan barış görüşmeleri sürerken temel konularda sorunlar yaşanmıştır. Kongre, Lozan'da kapitülasyonlar gibi Osmanlıyı sömürgeleştiren konularda sert tartışmaların yapılması üzerine görüşmelerin 4 Şubat 1923 tarihinde askıya alındığı bir konjonktürde düzenlenmektedir (Durmuş ve Aydemir, 2016: 163). Kongre görüşmelerin taraflar arasında çıan anlaşmazlık sonucu kesildiği bir zamanda taraflara mesaj verecek şekilde toplanmıştır. Osmanlı İmparatorluğu'ndan kalan borçlar, kapitülasyonlar gibi önemli bazı konularda anlaşma sağlanamaması üzerine kesintiye uğrayan Lozan görüşmelerindeki dayatmacı muhataplara bu konularda hiçbir şekilde ödün verilmeyeceğini (Durmuş ve Aydemir, 2016: 165) mesajı, Birinci İzmir İktisat Kongresinde verilmiştir. Kongrenin hazırlıkları müzakerelerin kesildiği bir dönemde Kurtuluş Savaşı'nı destekleyen toplum yapısı ve güç dengeleri(Korum, 1982: 64) dikkate alınarak organize edilmiştir. Kısacası zaferi kazanan yönetici kadro düzenlenen kongre aracılığıyla Lozan'da karşılaşılan zorlukları Türk ve dünya kamuoyuna duyurmakla (Özçelik, Tuncer, 2007: 255), kalmayıp, bazı ekonomik dayatmalarda 
Türk İşletme Tarihi ve Yönetim Bilimi Açısından Birinci İzmir İktisat Kongresi:

Banka Merkezli İşletme Gruplarının Oluşumu

bulunan taraflara cevap niteliğindeki kararları da almıştır. Kongrenin zamanlamasında dikkat çeken ikinci husus da, ülkenin yeni yönetim şeklinin ilan edilmeden önce yapılmasıdır. Kongre düzenlendiği zaman Kurtuluş Savaşı zafer ile sonuçlanmış, ancak devletin yeni yönetim şekli henüz belirlenmemiştir. Kongrede sekiz ay sonra ilan edilecek yeni yönetim şeklinin ekonomik altyapısı ilan edilmiştir. İzmir İktisat Kongresi’nin zamanlaması görüşülen konuların ne kadar öncelikli olduğuna işaret etmektedir.

Kongre'de yapılan görüşmeler kadar katılımcılarının özellikleri de dikkat çekicidir. Kongrenin katılımcıları farklı gruplardan; çiftçi, tüccar, sanayici ve işçi gruplarından oluşmuştur. Dönemin ekonomik koşullarını temsil eden farklı grupların kongreye katılımı etkili sonuçların alınmasını sağlamıştır. İşgal ve savaş, tüccar ve esnafların Ankara hükümeti ile irtibatlarını zorlaştırmıştır. İstanbul ve İzmir illerinde bulunan sermaye çevrelerinin, Ankara hükümeti temsilcileri ile yakınlaşmasını sağlaması ve yeni kurulacak cumhuriyetin ekonomi politikalarını kendilerine bildirmesi (Kahraman ve Şişmanoğlu, 2019: 630) Birinci İzmir İktisat Kongresi sayesinde olmuştur. Düzenlenen kongre ile tüccarların çiftçilerin, sanayicilerin ve işçilerin sorun ve isteklerinin neler olduğunu bilmek/belirlemek (Durmuş ve Aydemir, 2016: 158) imkânı elde edilmiştir. Kurtuluş Savaşı'ndan sonra İstanbullu Türk tüccarlar Milli Türk Ticaret Birliği'ni kurarak yabancı ekonomilerle, dış ekonomik ilişkileri sürdüren azınlıkların tasfiyesiyle meydana gelen boşluğu doldurmayı (Koçtürk ve Gölalan, 2010: 50) amaçlamışlardır. İşgal sırasında tütün tekeli kurulması, işletilme hakkının yabancı sermaye egemenliğindeki bir şirkete verilmesi tehlikesi karşısında yerli tüccarlar arasında işgal sonrası Milli Türk Ticaret Birliği’nin kurulmasına neden olmuştur. Birliğin kurulması esnaf ve tüccarların milli bir kongreye katılımının altyapısını sağlamıştır.

Kongre 16 günlük yoğun bir mesai sonrası tamamlanmıştır. Kongrede alınan kararlar tavsiye niteliği taşımaktadır. İzmir İktisat Kongresi'nde alınan kararlar hükümeti bağlayıcı nitelikte kararlar değildir (Koç, 2010: 155). Kongre kararları, Türkiye Büyük Millet Meclisi Başkanlığı ile Bakanlar Kurulu Başkanlığına takdim olunmuştur (İnan, 1989: 20). Kongre sonrasında yapılan düzenlemeler ve yeni girişimler alınan kararların dikkate alındığının birer göstergesidir.

Kongrede alınan ana kararlar; şirketleşmeyi kolaylaştırmak, sanayiyi teşvik, milli bankalaşma, milli yerli üretimi teşvik, teknik eleman yetiştirecek okullar açmak, demir yolları inşaatının hükümetçe bir programa bağlanması, sanayi mallarının gümrük vergileri ile korunması, ulaşım sorunlarının çözülmesi (Keçetep, 2016: 826), tekelleşmenin önlenmesi, reji kaldırılıp tütün faaliyetlerinde serbesti sağlanması, aşar vergisi kaldırılması, yabancı sermayeye ülke ekonomisinin öncelikleri doğrultusunda izin verilmesi (Kahraman ve Şişmanoğlu, 2019: 631) şeklinde özetleyebiliriz. Alınan kararlar ve yayınlanan belge ekonomik kadroya da yön verici niteliktedir. Toplumda iktisadi düşüncenin gelişmediği, aydınların da iktisadi bilgilerinin dar olduğu bir dönemde düzenlenen kongre sonunda, böyle bir belgenin yayınlanmış olması büyük önem taşımaktadır (Koç, 2010: 152). Kısacası kongre, Cumhuriyetin ilanından önce hükümetin kuruluşundan sonra Türkiye’yi ileri ülkeler düzeyinde 


\section{Muzaffer AYDEMIR}

yükseltmek ve bu amaçla uygulanabilecek bir iktisat politikasını tayin etmek için (Köksal velllkin 1973: 5) yapılmıştır.

Tüm bu iktisadi hususların yanında kararların yarattığı örgütsel modeller en az kararlar kadar önem taşımaktadır. Kongrede alınan kararlar ışığında milli kalkınmayı sağlayacak, birçok eksikliği, ihtiyacı aynı yapı altında karşılayabilecek yeni örgütler ortaya çıkmıştır. Cumhuriyetin ilanından sonra kurulan yeni örgütsel yapıların kuruluş esasları kongrede alınan kararlar ile belirlenmiştir.

\section{Yeni İşletmelerin Ortaya Çıkışı ve Tarihsel Dönüşüm Metodolojisi}

İşletme tarihi çalışmaları, mikro ve makro ekonomik düzeyler arasında (Amatori ve Jones, 2007: 19), kurumsal ortamlarda işletmelerin ortaya çıkışındaki kurumsal, örgütsel nedenler, gelişmeleri, geçirdiği safhalar ile yaşanan değişimlerin nedenleri ve süreçlerve sonuçlar üzerinde durmaktadır. Yapılan çalışmalarda ülke kalkınmasının taşıdığı önem işletmelerin ortaya çıkışının nedenleri arasında yer almaktadır. İşletme tarihi çalışmalarında örnekler genellikle öncü konumundaki işletmeler olmaktadır (Sivramkrishna, 2014; Pozzi, 2014). İşletme tarihi çalışmaları niceliksel ekonomik kaynaklar yanında değerli niteliksel verileri de kullanarak yönetim bilimine ciddi katkılar sağlamaktadır.

İşletme tarihi çalışmalarında kullanılan önemli yöntemlerden birisi de tarihsel dönüşüm metodolojisidir. Tarihsel dönüşüm metodolojisi, kuramı ve tarihi bütünleştirilmeye yönelik çabalarının eleştirel bir değerlendirilmesi yoluyla (Lazonick, 2007: 53) uygulanmaktadır. Bu yaklaşımda karşıllıklı etkileşimlerin sonuçları değerlendirilmektedir. Tarihsel dönüşüm metodolojisi, toplumsal analiz birimlerini belirler ve sonuçta iktisadi gelişme sürecinde değişik toplumsal birimlerin birbirleriyle nasıl etkileştiklerini belirlememize olanak sağlar (Lazonick, 2007: 47).

Tarihsel dönüşüm metodolojisinde yenilikçi işletmenin toplumsal koşulları incelenmektedir. Söz konusu koşullar, yenilik sürecini teşvik eden ya da kısıtlayan sektörel, örgütsel ve kurumsal koşulların temel özellikleridir (Lazonick, 2007: 49). Yenilikçi işletmeyi anlayabilmemizi sağlayacak koşullar; sektörel (teknoloji, piyasa ve rekabet), örgütsel (bilişsel, davranışsal, stratejik), kurumsal (istihdam, mali, düzenleyici) koşullar (Lazonick, 2007: 49) olarak sınıflandırılmaktadır.

Yenilikçi işletmeler değişken koşulların var olduğu ortamlarda ortaya çıkmaktadırlar. İşletmelerin ortaya çıkmasını sağlayan koşullar zamanla değişmektedir. Koşullar ve ortaya çıkan işletmeler arasındaki ilişkiyi anlamamızı sağlayan yaklaşım tarihsel dönüşüm metodolojisidir. Tarihsel dönüşüm metodolojisinde yeni işletmeler çalışma ortamındaki farklı koşullara bağlı olarak var olmakta, örgütsel şekil almaktadırlar. Yeni işletmelerin ortaya çıkışlarını doğru bir şekilde anlayabilmemiz için dönemin koşullarını iyi bilmemiz, değerlendirmemiz gerekmektedir.

İşletme tarihi çalışmaları sadece mikro düzeydeki işletmeleri, örgütsel yapıları anlamada değil makro düzeydeki çabaları da anlamamızı sağlamaktadır. İşletme tarihi çalışmalarında makro ve mikro 
Türk İşletme Tarihi ve Yönetim Bilimi Açısından Birinci İzmir iktisat Kongresi:

Banka Merkezli İşletme Gruplarının Oluşumu

düzeylerin etkileşimi ve bunların örgütsel sonuçları önemlidir. Tarihsel dönüşüm metodolojisi, mikro ve makro düzeyleri birbirine bağlayarak işletmeleri, ulusal ve uluslararası ekonomik kalkınmanın evrimini anlamamıza yardımcı olmaktadır (Amatori, 2009: 17). Yenilikçi işletmeleri doğru anlamak için ortaya çıktıkları koşulları anlamak gerekmektedir.

\section{Tarihsel Dönüşüm ve Kurumsal Koşullar}

Tarihsel dönüşüm metodolojisinde yenilikçi işletmeyi anlayabilmemizi için sektörel, örgütsel ve kurumsal koşulların yeni işletmelerin ortaya çıkışlarındaki etkileri incelememiz gerekir. İzmir İktisat Kongresi doğrudan spesifik yeni bir işletmenin kurulmasını değil milli kalkınmayı sağlayacak stratejik örgütsel esasların belirlenmesi amaçlanmıştır. Bu kapsamda, spesifik bir işletme, örgütsel yap1 incelenmediğinden örgütsel dönüşüm metodolojisinde yer alan sektörel örgütsel ve kurumsal koşullardan sadece kurumsal koşullar incelecektir.

Şekil 1'de Birinci İzmir İktisat Kongresinin toplandığ1 dönemde etkili olan koşullar ve kongre sonrası ortaya çıkan ana örgütsel yapılar yer almaktadır. Kongre toplanmadan önce ortaya çıkan ve kongrenin çalışmalarında doğrudan etkisi bulunan koşullar kurumsal koşullar olarak üst kısımda belirtilmiştir. Bahse konu koşulların şekillendirdiği kongre süreci öncesi ve sonrası meydana gelen değişimler de altta belirtilmiştir.

Tarihsel dönüşüm metodolojisinde yeni örgütsel yapıların ortaya çıkışı ve bu çıkışın nedenleri ortaya konmaktadır. Kurtuluş Savaşı sonrasında yaşanan dönüşümlerin nedenlerini biraz daha gerilerde aramak gerekmektedir. Birinci Dünya Savaşı'ndan başlayan süreç kurumsal koşulları üzerinde belirleyici olmuştur. Savaşın kurumsal koşullarının olumsuz yansımaları şekil 1'de de görüldüğü gibi tüm ekonomik ve toplumsal şartları negatif yönde etkilemiştir. Yaşanan savaşlar, ülkenin mali yapısını daha da zayıflatmış, sınırlı olan sanayi üretimi gerilemiş, milli üretim ve kalkınma ihtiyacı hat safhaya ulaşmıştır. Savaşlar ülkenin demografik yapısını, nüfusunun nitelik ve nicelik özelliklerini olumsuz şekilde etkilemiştir. Ülkenin milli kalkınmasını sağlayacak girişimcilerin ortaya çıkması savaşlar nedeniyle mümkün olamamıştır. Birinci Dünya Savaşı ile 1925 yılları arasına baktığımızda yaşanan olayların önemli bir kısmı politik olaylardır. Savaşın doğal sonucu olan politik olaylar yanında dikkat çeken süreç Birinci İzmir İktisat Kongresi’nin toplanması ve sonrasıdır. Kongrenin şekillendirdiği koşullar iki önemli örgütsel yapıyı, banka merkezli işletme grubunu meydana çıkarmıştır. Cumhuriyetin ilanından bir yıl gibi kısa bir süre sonra kurulan İş Bankası ile Sanayi ve Maadin Bankası'nın örgütsel esasları Birinci İzmir İktisat Kongresi'nde belirlenmiştir. 
Şekil 1. Birinci İzmir İktisat Kongresinin toplandığı dönemdeki tarihsel dönüşüm koşulları

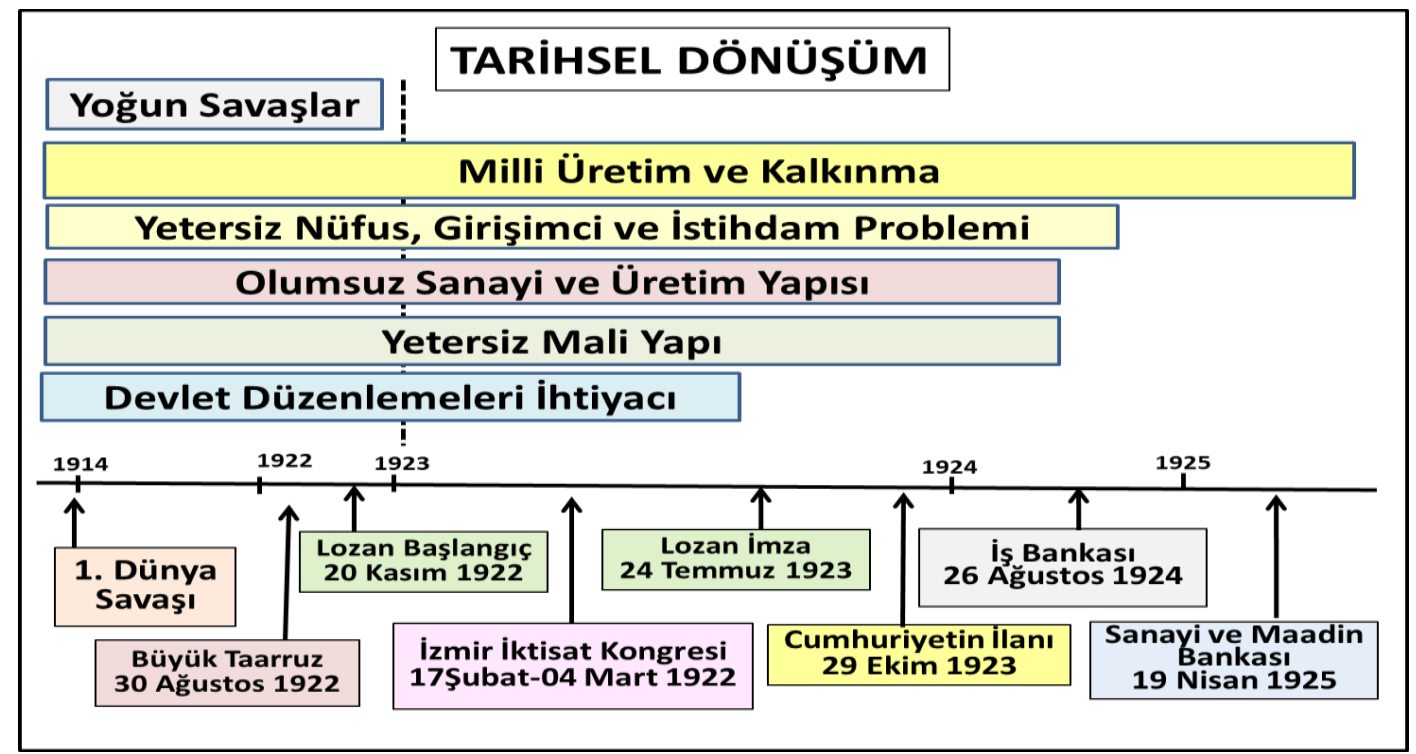

Tarihsel dönüşüm metodolojisinde, ortaya çıkan yeni işletme ve örgütsel yapıların makro düzeyde doğru bir şekilde anlaşılabilmesi için dönemin genel koşulları olan kurumsal koşulların doğru bir şekilde ortaya konması gerekmektedir. Birinci İzmir İktisat Kongresi'nin toplanma nedenlerini oluşturan ve uzun bir geçmişe dayanan koşullar anlaşılmadan kongre sonrası ortaya çıkan örgütsel yapıları doğru bir şekilde değerlendirmek mümkün değildir. Tablo 1'de Birinci İzmir İktisat Kongresi'nin toplandığı dönemde kurumsal koşullar ve bunların ortaya çıkan yeni örgütsel yapılar üzerine etkileri ele alınmıştır.

Tablo 1. Birinci İzmir İktisat Kongresi dönemindeki kurumsal koşullar ve etkileri

\begin{tabular}{|c|c|c|c|}
\hline Koşullar Sistemi & Alt Koşullar & Mevcut Koşullar & Koşulların Sonuca Etkileri \\
\hline \multirow{4}{*}{ Kurumsal Koşullar } & Savaşın Yarattığı Koşullar & $\begin{array}{l}\text { Yeni bitmiş zaferle sonuçlanmış } \\
\text { yıkıcı savaşın olumsuz etkileri }\end{array}$ & $\begin{array}{l}\text { Savaşın yarattığı olumsuz koşulları } \\
\text { ortadan kaldırmak için milli } \\
\text { kalkınma esaslarının belirlenmesi }\end{array}$ \\
\hline & Sanayi, Üretim Koşulları & $\begin{array}{c}\text { Sanayinin, üretimin ilkel koşullarda, } \\
\text { yetersiz düzeyde yapılması. }\end{array}$ & $\begin{array}{l}\text { Milli kalınmayı gerçekleştirebilecek } \\
\text { güçlü örgütsel yapıların, } \\
\text { işletmelerin esaslarının } \\
\text { belirlenmesi. }\end{array}$ \\
\hline & Mali Koşullar & $\begin{array}{l}\text { Kısıtlı mali piyasa imkanları, güçlü } \\
\text { mali örgütsel yapılar, bankaların } \\
\text { yabancıların sahipliğinde olması }\end{array}$ & $\begin{array}{c}\text { Sanayileşme, kalkınmayı } \\
\text { sağlayacak güçlü milli bankalara } \\
\text { ihtiyaç }\end{array}$ \\
\hline & İstihdam Koşulları & Ülkedeki insan kaynakları & $\begin{array}{c}\text { İnsan gücünün kalkınma için } \\
\text { niteliksel ve niceliksel olarak } \\
\text { yetersiz olması }\end{array}$ \\
\hline
\end{tabular}


Türk İşletme Tarihi ve Yönetim Bilimi Açısından Birinci İzmir iktisat Kongresi:

Banka Merkezli İşletme Gruplarının Oluşumu

\begin{tabular}{|c|c|c|c|}
\hline Girişimci Yapısı & Ülkedeki girişimcilerin özellikleri & $\begin{array}{c}\text { Mevcut iş insanlarının esnaf ve } \\
\text { tüccar olması, }\end{array}$ \\
\cline { 2 - 4 } & Düzenleyici & Devlet düzenlemelere olan ihtiyaç & $\begin{array}{c}\text { Lozan Barış Anlaşması } \\
\text { görüşmelerinde borçlar ve } \\
\text { kapitülasyonlar ve hukuki konularda } \\
\text { gerekli düzenlemelerin yapıllması. }\end{array}$ \\
\hline
\end{tabular}

Osmanlı İmparatorluğunun üretim sistemi tarım yanında loncalar, esnaf sistemine dayalı idi. Geniş bir coğrafyaya hükmeden, İpekyolu üzerinde olan imparatorluk uzun süre güçlü bir ekonomik bir güce sahip idi. Amerika'nın keşfi sonucu Avrupa'ya kıymetli metallerin gelmesi, Ümit Burnu'nun geçilerek Asya'nın güneyi ve doğusunun ekonomik sisteme katılması ve özellikle buhar gücünün keşfi ve sanayide kullanılması dünya dengelerini önemli ölçüde değiştirmiştir. Sanayileşme ve kitle üretim sistemi sonunda daha fazla hammadde ihtiyacı ortaya çıkmış, Osmanlı İmparatorluk toprakları Batı için güçlü bir pazar olmanın yanında hammadde kaynağı olmuştur. Esnaf, loncalardan daha fazla ürünü daha ucuza üreten Batı karşısında imparatorluk topraklarında hammadde fiyatlarını yükseltmiş, üretim sistemi zarar görmüştür. Uzun süre devam eden süreç sonunda imparatorluk toprakları kârlı bir pazara dönüşmüştür. Yapılan anlaşmalar ile İngiltere başta olmak üzere Batılı devletlere tanınan imtiyazlar, kapitülasyonlar Osmanlı İmparatorluğu için olumsuz neticeler yaratmıştır Osmanlı pazarının bu açılımı mevcut sanayiyi yıkmış ve sanayileşme çabalarını boşa çıkarmıştır (Georgeon, 2006: 190).

19. yüzyıl boyunca sanayileşmesini tamamlamış olan Batı Avrupa 20. yüzyıl ilk yıllarında ekonomik alanda güçlü bir duruma gelmiştir (Köksal ve İlkin, 1973: 3). Sanayileşme Batıdaki sermaye birikimini artırmış yeni ve güçlü girişimlerin, güçlü işletmelerin kurulmasını sağlamıştır. Buna karşılık Osmanlı Devleti sanayileşme hamlesini yapamamış, ilkel ve tarıma büyük ölçüde bağlı bir ülke olmuştur (Köksal ve İlkin, 1973: 3).

Ekonomik koşullar yanında yaşanan ve kaybedilen yıkıcı savaşlar da imparatorluk ekonomisine olumsuz etkilerde bulunmuştur. Orduyu teçhiz etmek için alınan borçlar devlet hazinesine ilave yük getirmiştir. Girilen savaşların kaybedilmesi, ödenen tazminatlar ve yeni borçlanmalar ekonomik durumu daha da kötüleştirmiştir. Yıkıcı savaşlar yalnız ekonomiyi değil toplumu da olumsuz şekilde etkilemiştir. Anadolu bozkırının geçimlik üretime mahkum kıldığı geniş ve yoksul köylü kitlesi 10 yılı aşkın savaş ve yıkım döneminin en çok sarstığı sınıfı oluşturmuştur (Boratav, 1988: 27).

1900 başına gelindiğinde tablo çok daha olumsuz bir hal almıştır. 1908-1914 yılları arasında Osmanlı İmparatorluğu'nun ekonomik yapısı tarımcı, sanayide fevkalade geri, dış ticarette dışa bağımlı niteliklerini büyük ölçüde korumuştur (Boratav, 1988: 23). Alınan ve bir türlü ödenemeyen 


\section{Muzaffer AYDEMiR}

dış borçlar diş ticaretin artan açıkları yöneticileri yeni arayışlara yönlendirmiştir. Girişimci azlığı ve sermaye kısıtlılığı karşısında devlet sanayi işletmeleri kurma yoluna gitmiştir. Dışa bağımlılık ve sermaye yetersizliği gibi problemler özellikle askeri ihtiyaçların karşılanabilmesi için devletin sanayi işletmesi kurmasını zorunlu hale getirmiştir (Tuna, 2009: 18).

Balkan ve Birinci Dünya Savaşı sonunda koşullar devlet ve halk için daha da olumsuz olmuştur. I. Dünya Savaşı ekonomik yönden zayıf olan yurdumuzu daha da zor bir duruma düşürmüştü (Köksal ve İlkin, 1973: 3). Birçok cephede aynı anda yapılan savaşların çoğu kaybedilmiş, sahip olunan toprakların çoğu elden çıkmıştır. Kaybedilen topraklar sonunda İmparatorluk ekonomisi belirli alanlarda toplanmıştır. Osmanlı İmparatorluğu'nun çöktüğü dönemlerde Türkiye ekonomisibu alanda kapitalist metropollere büyük ölçüde bağımlıdır (Tezel, 2015: 121). Bu dönemde, sanayileşmede sanayinin bölgeler arasındaki dağılımı dengesizdir (Türk, 1970: 10). Bu merkezlerin Kurtuluş Savaşı öncesi işgali kontrolün işgal güçlerine geçmesine neden olmuştur.

Kurtuluş Savaşı esnasında ve sonundaki istatistiki veriler dönemin kurumsal ortamı hakkında fikir sahibi olmamızı sağlamaktadır. Kongre öncesi yapılan istatistik sayımları dönemin koşulları hakkında fikir edinmemizi sağlayabilecektir. Son Osmanlı sanayi istatistik sayımları 1913-1915 yılları arasında yapılmıştır. İmparatorluk topraklarındaki üretim yapan işletmeler basit teknolojik yeteneğe sahip, sektörel olarak da Avrupa sanayisi ile rekabet gücünden yoksundu. Üretim yapan örgütsel yapılar ağır sanayiden uzaktılar, toplumun temel ihtiyaçlarını karşılamaya yönelik faaliyet göstermekteydiler. İmparatorluğun şehir ve kasabalarındaki işletmeler, halkın temel ihtiyaçlarını karşılayacak maddeleri üretmekteydiler. Genel tablo içerisinde, gıda sanayi 1913 yılında \%68.6, 1915 yılında \%70.3, dokuma sanayi de \%14.9, 1915 yılında da \%11.9 oranına (Ökçün, 1971: IX) sahipti.

İzmir İktisat Kongresi öncesi 1921 yılında yapılan sanayi sayımları, savaş sürecinin etkilerini göz önüne sermektedir. 1921 yılında milli sınırlar içinde faaliyet gösteren 33.058 işletmenin \%60.7 dokuma çalışan $\% 46.3$, deri $\% 16.2$ çalışan $\% 23.6$, maden $\% 9.9$ çalışan $\% 10.5$, tahta $\% 6.3$ çalışan $\% 7.9$, gida $\% 3.8$ çalışan $\% 5.9$, toprak $\% 2.1$ çalışan $\% 4.7$ ve kimya $\% 1$ çalışan $\% 1.1$ 'dır (Türkdoğan, 1981, 457). Türkiye'nin 1923 sınırları esas alındığında yerli fabrika üretiminin yurtiçi tüketimi karşılama oranı pamuklu kumaşlarda $\% 10$, yünlü kumaşlarda $\% 40$, ipekli kumaşlarda $\% 5$, sabunda $\% 20$, buğday ununda \%60 olup porselen, cam, çatal bıçak, şeker gibi tüketim mallarında tamamı ithaldir (Tezel, 2015: 121).

Birinci İzmir İktisat kongresi öncesinde büyük işletmelerin çoğunluğu yabancıların mülkiyetindedir. 1920'lerin başında Türkiye ekonomisinde önemli bir yer tutan yabancı sermaye şirketlerinin ülkedeki öz varlıklarının \%45 Alman, \%26 Fransız, \%17 İngiliz, \%4 Belçika, \%2 Amerikalılara ait olup toplamı 63 milyon sterlin kadardır (Tezel, 2015: 126). Yerli girişimcilerin sahip

olduğu işletmeler ortalama 3'den az çalışanı olan atölyeler şeklindedir. Kurtuluş savaşı sonrasında 
Türk İşletme Tarihi ve Yönetim Bilimi Açısından Birinci İzmir iktisat Kongresi:

Banka Merkezli İşletme Gruplarının Oluşumu

ekonomi genellikle küçük işletmelerin hakim olduğu bir örgütlenme biçiminde idi (Türkdoğan, 1981: 456).

Kongre öncesi finansal örgütlerin, bankaların sahiplik yapıları, kuruluş amaçları dikkat çekicidir. Cumhuriyetten önce piyasada faaliyet gösteren bankalar daha çok yabancı sermaye tarafından ya da yabancı iştirakiyle, özellikle Türkiye'de faaliyette bulunan yabancı şirketleri finanse etmek amacıyla kurulmuştur (Parasız, 1998, s. 109). Bankaların uygulamaları dikkate alındığında amaçlarının imparatorluk mali yapısını güçlendirmekten çok kendi beklentilerini karşılaşmak olduğu görülmektedir. Savaş öncesi dönemde bankaların başlıca faaliyetleri kamu borçlarını düzenlemek, aracılık etmek ve ülkedeki yabancı yatırımcıları yönlendirmekti (Keyder, 1998: 115).

Osmanlı İmparatorluğu'nun son dönemi ile Cumhuriyetin kuruluşunu takip eden dönemde kurulan bankalar salt finansal ve iktisadi açıdan ele alınmamalıdır. Anılan dönemde kurulan bankalar zamanın ekonomik, sosyal, siyasi yönetsel özelliklerini yansıtmaktadırlar. 1909 yılından itibaren milli kalkınma hareketi kapsamında birçok yerel banka kurulmuştur. Özellikle kasabalardaki Türk toprak sahipleri ve tüccarlar tarafından örgütlenmiş olan bu bankaların kuruluşunda genellikle siyasal iktidarın milletvekillerinin öncü olduğu göze çarpmaktaydı (Kazgan vd., 1999: 81). Yerel tüccar bölgenin ileri gelenleri, girişimciler tarafindan 1909 yıllından itibaren başlayan bankacılık hareketi 1930 yılına kadar sürmüştür. Söz konusu dönemde toplam 49 adet yerel banka kurulmuştur (Ökçün, 1973: 415-458). Kurulan 49 bankanın 21 adedi İzmir İktisat Kongresi öncesinde kurulmuştur. Anadolu bankaları ihracatta yabancı sermaye hâkimiyetiyle rekabet olanakları sağlamaya yönelik yerel tüccar örgütleri niteliğindeydi (Keyder, 1998: 115). Özellikle şehir ve kasabalardaki Türk toprak sahipleri ve tüccarlar tarafından örgütlenmiş olan bu bankaların kuruluşunda genellikle siyasal iktidarın milletvekillerinin öncü olduğu göze çarpmaktaydı (Kazgan, vd., 1999: 30-II).

Savaşın yarattı̆̆ olumsuz koşullar finansal yapılarda da kendisini göstermiştir. Savaş esnasında ve sonrasında ülke topraklarında yabancı sermaye azalmaya başlamıştır. Bu hareketlilik yerel girişimleri de olumsuz şekilde etkilemiştir. Savaş sırasında hem Fransız hem İngiliz sermayesinin ülkeyi terk zorunda kalması hem de tarım fiyatlarının artması nedeniyle bol kâr getiren mali girişimlerin kalıcı faaliyetler olmadığı daha sonra görüldü (Keyder, 1998: 115).

Kurtuluş Savaşı sonrası finansal yapıyı etkileyen önemli faktörlerden birisi de İmparatorluğun borç stokudur. Osmanlı İmparatorluğu'ndan kalacak olan dış borçlar (Yaşa, 1980: 563) yeni yönetici kadronun çözmesi gereken önemli sorunlardan birisidir. Lozan görüşmelerinin çetin geçmesinin ana nedenlerinden birisi de borçlar meselesidir. Lozan anlaşması sonrasında uzun bir döneme yayılacak olan imparatorluk borçları genç Cumhuriyetin mali yapısında bazı zorlukların yaşanmasına neden olmuştur. Borç meselesi yanında yabancılara tanınan gümrük imtiyazları ve kapitülasyonlar da imparatorluktan miras kalan, kalkınma önünde engel oluşturan konulardandır. 
Milli kalkınmanın önündeki önemli kurumsal engellerden birisi de ülkenin demografik yapısı ve kaynaklarının durumudur. Kurtuluş Savaşı sonrası ülkenin nüfus yapısı da diğer koşullar gibi olumlu değildi. Uzun süren yıkıcı savaşlar ülkenin genç işgücünü azaltmıştır. Nüfus yapısı incelenirken nicel ve nitel özellikleri önem kazanmaktadır. Kurtuluş savaşı bittiğinde ülke nüfusu 10 milyon civarında idi. Gençlerini savaş meydanlarında yitiren ülke mevcut nüfusu ile kalkınmak mecburiyetindedir. Cumhuriyetin başlangıcında nüfus yaklaşık \%77'si köylerde yaşıyor, çalışan nüfusun \%81'i tarımla uğraşırken \%5,6's1 sanayi \%4,8'i ticaret ve \%7'si de hizmet sektöründe istihdam ediliyordu (Kazgan, vd., 1999: 30-II).

Kurtuluş Savaşı sonrası demografik yapının nicelikleri kadar nitelikleri de olumsuzdur. Mevcut nüfusun nitelikleri de ülke kalkınması için yeterli özelliklere sahip değildir. Öncelikle okuma yazma oranı oldukça düşüktür. 1920'lerin başında tipik bir az gelişmiş bir ülke durumunda olan Türkiye'de okuma yazma oranı \%10 dolayındadır (Yaşa, 1980: 563). Milli kalkınmanın gerçekleşebilmesi için yüksek bir okuma yazma oranına sahip yetişmiş bir nüfusa ihtiyaç duyulmaktadır. Kalkınma için nüfusun niteliklerinden birisi de girişimci varlı̆̆ıdır. Savaş sonrası ülkede iktisadi açıdan öne çıkan kesim esnaf ve tüccarlardır. Çoğu yöresel boyutta faaliyette bulunan esnaf ve tüccarlar sınırlı sayıda üretim kapasitesine sahip işletmelerde üretim yapmakta, ürünlerini bölgesindeki tüketici kesime sunmaktaydılar. Büyük şehirlerdeki tüccarlar ise çoğunlukla yabancı şirketlerin temsilcileri idiler. Sanayileşmek, kalkınmak için öncelikle kalkınmayı sağlayacak işletmeleri, örgütsel yapıları kuracak girişimci sınıfına ihtiyaç vardır. İzmir İktisat Kongresi düzenlendiğinde yeterli düzeyde milli kalkınmayı gerçekleştirebilecek sanayici, girişimcilerin olduğu söylenemez. Bu dönemde ülkenin lider kadrosu asker kökenli kişilerden oluşmaktaydı. Hayatları savaş meydanlarında geçmiş, stratejik kararlar vermiş ve verdiği kararlar sonucu zaferi kazanmış kadro, milli kalkınmaya yönelik stratejik karar ve uygulamaları da yerinde ve zamanında yaptılar. Kendileri girişimci olmasa da güçlü girişimci kadroları oluşturmak için kongreyi topladılar.

\section{Birinci İzmir İktisat Kongresi ve Yeni İşletme Kurulması}

Kurtuluş Savaşı'nın hemen sonrasında düzenlenen Birinci İzmir İktisat Kongresi’nde gelecek dönemde uygulanacak yeni kalkınma stratejileri belirlenmiştir. Savaş sonrası ülkenin hızla kalkınması gerekmektedir. Kongrede, milli kalkınmanın gerçekleşebilmesi için yol haritası, ana esasların belirlenmesi hedeflenmiştir. Ekonomik kalkınma konusuna bu kadar büyük önem vermekle beraber açıklığa kavuşturulması gereken bir nokta bulunmaktadır; o da kalkınmanın ne yolda ve hangi strateji ile gerçekleştirileceği fikridir (Koç, 2010: 149). Kongrede tartışılan ana konulardan birisi de ülkede ivedilikle savaşın izlerinin silinmesi, hedeflenen kalkınma için sanayileşmenin nasıl sağlanacağıdır.

Kongreye çeşitli sektörlere ait çalışma gruplarının temsilcileri katılmıştır. Kongrede, kalkınma modeli ve bunun nasıl başarılabileceği konuları öncelikli olmak üzere sektör temsilcilerinin görüşleri alınmıştır. Zaferi kazanan yönetici kadro kalkınma modeli arayışları konusunda açılık sağlayabilmek 
Türk İşletme Tarihi ve Yönetim Bilimi Açısından Birinci İzmir İktisat Kongresi:

Banka Merkezli İşletme Gruplarının Oluşumu

maksadı ile bir iktisat kongresi toplanmasının doğru olacağını (Koç, 2010: 149) düşünerek kongre düzenlemiştirler. Kongrede; milli kalkınma nasıl sağlanacak, sanayileşmek için hangi tip örgütsel yapılar oluşturulacak, toplum kısa sürede nasıl daha iyi bir refah düzeyine ulaştırılacak gibi soruların cevapları bulunmaya çalışılmıştır.

Kongrede sanayileşmenin hangi yöntemle yapılacağı görüşülmüştür. Bu konuda iki alternatif bulunmaktadır; özel sektör veya devlet girişimleri. Birinci İzmir İktisat Kongresi’nde çok kesin bir sınır çizilmemekle birlikte sanayileşmek için özel girişimciliğin öne çıktığı görülmektedir. İzmir İktisat Kongresi 1şı̆̆ altında 1923 ’te başlayan bu dönemde özel kesime ağırlık verilmiştir (Köksal ve İlkin, 1973: 5).

Özel kesim veya kamu kesimini başarısı önemli eksikliklerin giderilmesine bağlıdır. Söz konusu eksikliklerden ilki toplumun temel ihtiyaçlarını karşlayacak ürünleri üretecek olan işletmelerin yokluğudur. Kalkınmanın gerçekleşebilmesi için örgütsel yapılara ihtiyaç duyulmaktadır. Güçlü örgütsel yapıların kurulabilmesi için de girişimcilerin sermaye yapılarının olması gerekmektedir. Yapılacak girişimlere finansal kaynak sağlayacak sermaye birikimine sahip örgütsel yapılar bankalardır. Bankalar, sahip oldukları sermayeyi girişimcilerin hizmetine sunarak farklı sektörlerde yeni işletmelerin kurulmasını sağlarlar. Kurtuluş Savaşı sonrasında ortaya çıkan önemli sorunlardan birisi de sermaye kıtlığıdır. Sermaye kıtlığı kongrede ele alınan öncelikli konulardan birisidir. Birinci İzmir İktisat Kongresi'nde sermaye birikimi eksikliğinin en önemli ekonomik problem olduğu göz önüne alınarak bankacılık konusuna özel bir önem atfediliyordu (Tuna, 2009: 24). Sermaye kıtlı̆̆ını giderecek, girişimcilerin ihtiyaçlarına cevap verecek bankalara olan ihtiyaç, sektör temsilcileri tarafından dile getirilmiştir. Özellikle tüccar grubu bankaya olan ihtiyaçlarını açıkça belirtmiştir. Kongre'de tüccar grubun ihtiyaçları belirlenirken; dağınık biçimde bulunan sermaye yapısının toparlanması, ilgili düzenlemelerin yapılması ve teminat ile kredi imkânları sağlayacak bankalara ihtiyaç duyulduğu dile getirilmiştir (Pıçak, Süloğlu ve Eker, 2017: 148).

\section{Birinci İzmir İktisat Kongresi ve Banka Merkezli İşletme Grubu}

İzmir İktisat Kongresinde ana hedef milli kalkınmanın sağlanmasıdır. Milli kalkınma için öncelikle güçlü örgütsel yapılara, işletmelere, şirketlere ihtiyaç duyulmaktadır. Kurtuluş Savaşı sonrası ülkede bu özellikleri taşıyan örgütsel yapıların olduğu söylenemez. İzmir İktisat Kongresi'nde eksiklerin tespit edilmesinin yanında çözümü sağlayacak örgütsel yapıların esasları da tespit edilmiştir. Cumhuriyetin ilk on yılında sanayinin gelişmesi için 1923 İktisat Kongresi kararları doğrultusunda gerçekçi ekonomik adımlar atılmıştır (Durmuş ve Aydemir, 2016: 160). Kongre milli kalkınmayı sağlayacak ekonomik alanlar ve örgütsel yapıların tespitinde oldukça etkili olmuştur. Kongre kararlarının etkisinin hissedildiği alanlar; para, kredi, bankacılık, mali sistem alanı, ulaşım sektörü, tarım sektörü, sanayi ve ticaret sektörü, dış ticari ilişkiler olarak sıralanabilir (Koç, 2010: 156). İzmir iktisat Kongresi'nin işleyiş süreci ve alınan kararlar detaylı olarak çalışılmasına rağmen kararların 


\section{Muzaffer AYDEMIR}

yarattığı örgütsel yapılar yönetim bilimi esaslarıyla ele alınmamıştır. Kongre sonrasında ortaya çıkan örgütsel modellerinin anlaşılabilmesi için öncelikle alınan kararların bilinmesi gerekmektedir.

Birinci İzmir İktisat Kongresi kongreyi düzenleyen lider kadronun dışında farklı grupların katılımı ile gerçekleşmiştir. Kongrede, “mesleki temsil” ilkesini temel alarak oluşturduğu işçi, tüccar, sanayici ve çiftçi grupları temsil edilmiştir (Pıçak, Süloğlu ve Eker, 2017: 146). Kongrede; farklı grupların sorunları ve çözüm önerileri görüşülmüş iktisadi konulara ait esaslar, tavsiye kararları alınmıştır. Hükümeti bağlayıcı nitelikte olmayan kararlar çeşitli sınıfların isteklerini ve ekonomiye bakışlarını göstermesi açısından önem taşımaktadır (Koç, 2010: 155).

Kongrede tüccar ve sanayi grubu yaptıkları toplantılarda milli kalkınma için yapılması gerekenlere ilişkin farklı konularda kararlar almışlardır. Katılımcılar tarafından alınan ve milli kalkınma önündeki engellerin aşılmasına yönelik olan ülke yönetim ekibine tavsiye niteliğindeki kararların örgütsel karşılıklarının neler olduğu incelendiğinde karşımıza iki ana konu çıkmaktadır, bankacılık ve işletmelerin, örgütsel yapıların teşkili. Yapılan toplantılarda tüccar grubu bankalar, sanayi grubu da sanayi bankalarına ilişkin kararlar aldılar. Çünkü dönemin koşullarında sermaye kıtlığı kalkınma önündeki ciddi bir engeldir.

Tüccar grubu ilk olarak bankalar meselesini ele almıştır. Toplantıda, münasip bir isim altında bir ticaret ana bankası kurulması kararlaştırılmış ve buna ilişkin esaslar (İnan, 1989: 32) belirlenmiştir. Benzer şekilde sanayi grubu da sanayi bankasının kurulması yönünde karar almıştır. Sanayiye yönelik uzun vadeli kredide uzmanlaşmış bir bankanın bulunmayışı, kendini açık bir biçimde hissettirmektedir ve böyle bir banka kurulması İzmir İktisat Kongresi'nde sanayiciler grubunun başlıca taleplerinden biri olacaktır (Georgeon, 2006: 192). Bu kapsamda, ziraat ve köy bankaları hariç, imtiyazlı birkaç bankanın sermaye katılımı ile sanayi bankasının kurulması (İnan, 1989: 50) düşünülmüş, bu kararlar üzerine tüm bu faaliyetleri yürütecek bir ana ticaret bankasının kurulması kabul edilmiştir (Pıçak, Süloğlu ve Eker, 2017: 148). Bankacılık yanında şirketleşme yeni ve güçlü işlemelerin kuruluşları ile ilgili esaslar da kongrede kararlaştırılmıştır.

İzmir İktisat Kongresi’nde bankacılık ve sanayileşme, şirketleşme konusunda alınan kararların ne gibi somut örgütsel karşılıklarının olduğu düşünüldüğünde karşımıza iki örgütsel yapı çıkmaktadır; İş Bankası ve Sanayi ve Maadin Bankası. Her iki banka da Cumhuriyetin ilanından sonra kurulmuştur. İş Bankası 1924 yılında, Sanayi ve Maadin Bankası da 1925 yılında kuruldu. Cumhuriyetin kuruluş yıllarında ülkenin uzun vadeli endüstriyel sermaye eksikliği problemine, İş Bankası ve Sanayi ve Maadin Bankası birlikte çözüm getirmişlerdir (Kandemir, 2002: 32).

İzmir İktisat Kongresi sonrası kurulan ilk kapsamlı örgütsel yapı İş Bankası'dır. Türkiye'de milli bankacılığın gelişmesi Cumhuriyetin başlangıcı ile olmuştur (Tezer, 1973: 13). Cumhuriyet kurulduktan bir yıl sonra kurulan İş Bankası sonraki dönem kurulacak örgütsel yapılar için bir model olmuştur. Türkiye Cumhuriyeti devleti ile Türkiye İş Bankası'nın kuruluş ve emekleme dönemi 
Türk İşletme Tarihi ve Yönetim Bilimi Açısından Birinci İzmir iktisat Kongresi:

Banka Merkezli İşletme Gruplarının Oluşumu

örtüşür (Kocabaşoğlu, vd., 2001: 17). Cumhuriyetin kuruluşu sonrası kalkınma için yeni girişimcilere ihtiyaç duyulmuştur. 1923 'te Cumhuriyetin kuruluşu ile birlikte devlet, yerli bürokrat, tüccar, işletme sahiplerini girişimci olma konusunda cesaretlendirdiler (Khanna ve Yafeh, 2007: 356). Ülke yöneticileri ve halkın geniş katılımıyla özel girişim olarak kurulan İş Bankası milli kalkınmanın ilk somut örgütsel örneğidir.

İş Bankası'nın kuruluşundan sonra kurulan önemli ikinci örgütsel yapı 1925 yılında Sanayi ve Maadin Bankası'dır. Sanayi ve Maadin Bankası özel bir kanunla, bir devlet kuruluşu olarak kurulmuştur. Banka Osmanlı İmparatorluğu'ndan kalan basit üretim teknikleri ile çalışan ve düşük üretim kapasitesine sahip işletmeleri devralmıştır. Sanayi faaliyetler; banka teessüs ettikten sonra dört fabrika; Feshane Yünlü Dokuma Fabrikası, Bakırköy Pamuklu Dokuma Fabrikası, Beykoz Deri ve Kundura Fabrikası ile Hereke İpekli ve Yünlü Dokuma Fabrikası'nı devralmıştır (Apak, Aydınelli ve Akın, 1952: 25). Banka farklı amaçları gerçekleştirmek için kanunla kurulmuştur. Banka, 19 Nisan 1925 tarihinde, 633 Sayılı Özel Yasayla kendisine devredilen olan müessesatı-sanayiye teşkil edecek şirketlere devredinceye kadar yönetmek, iştirak suretiyle sanayi faaliyetlerinde bulunmak, işletmek ve her türlü bankacılık işlemlerini yapmak üzere kurulmuştur (Akgüç, 1989: 157). 1925 yılında kurulan Sanayi ve Maadin Bankası daha sonraki dönemde kurulacak olan yeni girişimlere örnek teşkil etmiştir. Türkiye Sınai ve Maadin Bankası, özellikle 1950’li yılların başlarından itibaren, görülen kalkınma bankasının ilk örneklerinden biri olarak nitelendirilebilir (Akgüç, 1989: 24). Sanayi ve Maadin Bankası, İş Bankası'ndan farklı olarak diğer alandaki eksikliği gidermek amacıyla kurulmuştur. Sanayi ve Maadin Bankası'na devlet kuruluşları meydana getirmek görevi verilirken gaye, İzmir İktisat Kongresi'nde kabul edilen esaslara aykırı olarak özel kuruluşların yerini almak değil, daha çok onları tamamlamaktı (Serin, 1983: 106).

İzmir İktisat Kongresi sonrası kurulan iki önemli banka örgütsel yapıları yanında kuruluş amaçları ve işlevleri açısından incelendiklerinde bir banka olmanın ötesinde birer işletme grupları olarak görülürler. İş Bankası ile Sanayi ve Maadin Bankası'nın daha iyi anlaşılabilmesi için işletme grubunun ve özelliklerinin bilinmesi gerekmektedir. Tablo 2'deişletme grubu özellikleri ile İş Bankası, Sanayi ve Maadin Bankası'nın özellikleri karşılaştırılmaktadır. Cumhuriyet kurulduktan sonra kurulan her iki örgütsel yapı da banka olmanın ötesinde işletme grubu özellikleri taşımaktadır.

Tablo 2. İşletme grubu özellikleri ve İş Bankası, Sanayi ve Maadin Bankası

\begin{tabular}{|l|l|l|}
\hline İşletme Grubu Özelliği & Kuramsal Yaklaşımlar & I̧ş Bankası-Sanayi ve Maadin Bankası \\
\hline Örgütsel yapı & $\begin{array}{l}\text { İşletme grupları ana işletmenin yönetsel } \\
\text { kontrolü altında faaliyet gösterirler } \\
\text { (Khanna, 2000). }\end{array}$ & $\begin{array}{l}\text { İş Bankası iştirakleri, ana işletme olan bankaya bağlı olarak } \\
\text { faaliyet göstermiştir (Aydemir, 2019b, s. 58). } \\
\text { altında faaliyet göstermiştir (Aydemir, Özkaleli ve } \\
\text { Katırcığlu, 2012, s. 257) }\end{array}$ \\
\hline
\end{tabular}




\section{Muzaffer AYDEMIR}

\begin{tabular}{|c|c|c|}
\hline Taşıdıkları önem & $\begin{array}{l}\text { İşletme grupları, faaliyet gösterdikleri } \\
\text { ülkelerin ekonomilerinde önemli bir rol } \\
\text { oynarlar (Chung, 2001, s. 35) } \\
\text { İşletme grupları her yerde gelişmekte } \\
\text { olan ekonomilerde performansı büyük } \\
\text { ölçüde önemli bir şekilde etkilemektedir } \\
\text { (Khanna, Rivkin, 2001, s. 45) }\end{array}$ & $\begin{array}{l}\text { Her iki banka da Cumhuriyet sonrası kurulan ilk önemli } \\
\text { örgütsel yapılardır. } \\
\text { Cumhuriyetin ilk yııllarında sınai gelişmenin sağlanması için } \\
1923 \text { İzmir İktisat Kongresi'nde benimsenen kararlar } \\
\text { doğrultusunda alınan önlemlerden en önemlileri; önce 1924'te } \\
\text { İş Bankası (Georgeon, 2006, s. 193) ile Sanayi ve Maadin } \\
\text { Bankası'nın kurulmasıdır (Koçtürk, Gölalan, 2010, s. 53), }\end{array}$ \\
\hline Kalkınma ihtiyacı & $\begin{array}{l}\text { İşletme grupları gelişmekte olan } \\
\text { ekonomilerde performansı büyük } \\
\text { ölçüdeetkilemektedir (Khanna; Rivkin, } \\
\text { 2001, s. 45). }\end{array}$ & $\begin{array}{l}\text { Kalkınma modeli arayışları (Koç, 2010, s. 148) ve izlenecek } \\
\text { iktisat politikalarının ve iktisadi kalkınma hamlelerinin tespiti } \\
\text { için (Keçetep, 2016, s. 826) İzmir İktisat Kongresi } \\
\text { toplanmıştır. Tespit edilen esaslar çerçevesinde banka } \\
\text { merkezli işletme grubu özellikleri taşıyan iki bankalar } \\
\text { kurulmuştur. }\end{array}$ \\
\hline Örgütsel heterogeneti & $\begin{array}{l}\text { İşletme grupları iştirakleri farklı } \\
\text { sektörlerde faaliyet gösterirler } \\
\text { (KhannavePalepu, 2000). }\end{array}$ & $\begin{array}{l}\text { İş Bankası, tarım, sanayi, madencilik, enerji üretimi ve } \\
\text { dağıtımı, bayındırlık işleri, nakliyecilik, sigortacilık, turizm, } \\
\text { dışsatım alanlarında her türlü teşebbüsü kurmuş ve iştirak } \\
\text { etmiştir (Kocabaşoğlu, vd. 2001, s. 30). } \\
\text { Sanayi ve Maadin Bankası; Feshane Yünlü Dokuma Fabrikası, } \\
\text { Bakırköy Pamuklu Dokuma Fabrikası, Beykoz Deri ve } \\
\text { Kundura Fabrikası ile Hereke İpekli ve Yünlü Dokuma } \\
\text { Fabrikası devralmıştır (Apak, Aydınelli ve Akın, 1952, s. 25) } \\
\text { ve faaliyette bulunduğu süre boyunca } 16 \text { farklı alanda faaliyet } \\
\text { gösteren iştirake sahip olmuştur (Aydemir, Özkaleli ve } \\
\text { Katırcığlu, 2012, s. 256) }\end{array}$ \\
\hline Pazar etkinliği & $\begin{array}{l}\text { Gelişmekte olan piyasalarda işletme } \\
\text { grupları pazar imkanlarından } \\
\text { faydalanmak } \\
\text { kurulmaktadır(Khanna, Palepu, 2000, s. } \\
268 \text { ) } \\
\text { İşletme grupları faaliyette bulundukları } \\
\text { pazarlarda etkindirler (KhannavePalepu, } \\
2000)\end{array}$ & $\begin{array}{l}\text { İş Bankası, pazar eksikliklerine tepkiden daha çok sanayi } \\
\text { eksikliklerinin giderilmesi amacıyla hareket etmeye devam } \\
\text { etmiştir (Aydemir, 2019b, s. 60). } \\
\text { Sanayi ve Maadin Bankası, dönem içerisinde pazar şartlarını } \\
\text { yeterince oluşmamasına rağmen yönetsel şemsiyesi altındaki } \\
\text { sektör çeşitliliğine sahip işletmelerin pazar içerisinde etkin } \\
\text { olmasını sağlamıştır (Aydemir, Özkaleli ve Katırcıoğlu, 2012, } \\
\text { s. 257). }\end{array}$ \\
\hline Finansal ilişki & $\begin{array}{l}\text { İşletme grupları ana işletme ile iştirakler } \\
\text { arasında finansal ilişkiler vardır } \\
\text { (Ghemawat veKhanna, 1998; Khanna, } \\
\text { 2000). }\end{array}$ & $\begin{array}{l}\text { İş Bankası ticari kredilerin yanı sıra sınaî mülkiyette de aktif } \\
\text { olarak yer almaya başlamıştır (Ateş ve Soyak, 1999, s. 150). } \\
\text { Sanayi ve Maadin Bankası iştirakleri ile finansal ilişsiler tesis } \\
\text { etmiştir (Altug, 1981, s. 94). }\end{array}$ \\
\hline $\begin{array}{l}\text { Kuruluş } \\
\text { özellikleri }\end{array}$ & & $\begin{array}{l}\text { İş Bankası'nın kuruluş sözleşmesindeki } 4 \text { adet kuruluş amacını } \\
\text { yalnızca bir adedi bankacılık, diğerleri yönetim ve işletmecilik } \\
\text { işlemleri ile ilgilidir (Türkiye İş̧ Bankası Esas Mukavelesi, } \\
\text { 1946). } \\
\text { Sanayi ve Maadin Bankası kuruluş kanununda yer alan altı } \\
\text { amaçtan dördü işletmecilik ve yönetim, ikisi de bankacılık ve } \\
\text { finans ile ilgilidir (Recai, 1934, s. 31). }\end{array}$ \\
\hline
\end{tabular}


Dünyadaki hemen hemen birçok ülkede, farklı adlarla faaliyet gösteren işletme grupları ülkelerin ekonomilerde baskın konuma sahiptirler. Türkiye'de holding adı altında işletme gruplarının ortaya çıkışları 1960 sonrasına rast gelmesine rağmen Cumhuriyetin kuruluşundan kısa bir süre sonra işletme grubu özelliklerine sahip örgütsel yapılar hızla kurulmuştur. Türkiye Cumhuriyeti’ndeki işletme gruplarının ilk örnekleri İş Bankası ile Sanayi ve Maadin Bankasıdır. Her iki banka da literatürde iş grubu olarak adlandırılmaktadır. Cumhuriyet'in ekonomik tarihinde "İş Bankası Grubu" diye anılan bu kuruluşun yeri ve etkisi çok önemlidir (Yaşer, 1973: 343). Benzer şekilde Sanayi ve Maadin Bankası'nın da bir işletme grubu olduğu ifade edilmektedir. Zarakolu (1974) Sanayi ve Maadin Bankası'nın gerçek anlamda bir sanayi bankacılı̆̆ yapmaktan öte, bir sanayi holding şirketi gibi çalışmak zorunda kaldığını vurgulamaktadır. Söz konusu bankaların bir iş grubu oldukları söylenmesine rağmen yönetsel esaslarla konu açıklanmamıştır. Yönetim bilimi esasları ile Cumhuriyetin ilk iki bankasının birer banka merkezli işletme grubu oldukları Sanayi ve Maadin Bankası (Aydemir, Özkaleli ve Katırcıŏlu, 2012), İş Bankası (Aydemir, 2019b) ortaya konmuştur. Yapılan çalışmalarda, işletme grubu yaklaşımı ile bankalar karşılaştırılarak banka merkezli işletme grubu modeli Türk işletme tarihi çalışmalarına kazandırılmıştır. Söz konusu çalışmalar sadece örgütsel yapıların modelini belirlemiş, modelin esaslarının ortaya çıktığı süreçleri ele almamıştır. Banka merkezli işletme grubu modeli Birinci İzmir İktisat Kongresi'nde belirlenen esaslar çerçevesinde kurulan örgütsel yapılarda ortaya çıkmıştır. Özgün bir örgütsel yapı olan modelin kökeni gerçekte Birinci İzmir İktisat Kongresi' dir.

\section{Sonuç ve Değerlendirme}

Birinci İzmir İktisat Kongresi Türk tarihinde önemli bir yere sahiptir. Kongrenin tamamlanmasını müteakip birkaç ay sonra Lozan Barış Anlaşması imzalanmış ve Türkiye Cumhuriyeti kurulmuştur. Birçok önemli politik olay arasında yapılan kongrede devletin makro düzeydeki ekonomik esasları belirlenmeye çalışılmıştır. Birinci İzmir İktisat Kongresi’nin tarih ve iktisat bilimleri yanında işletme, yönetim bilimi aşısından da önemi büyüktür. Kongrede alınan kararlar sonrasında ortaya çıkan örgütsel yapılar yönetim bilimi yaklaşımları ile incelenmeye değerdir.

Birinci İzmir İktisat Kongresi yapıldıktan ve Cumhuriyet ilan edildikten sonra iki önemli örgütsel yapı ortaya çıkmıştır. İş Bankası ve Sanayi ve Maadin Bankası. Kongreye katılan tüccar ve sanayi grubu girişimlerine finansal destek sağlayacak sanayi bankasının kurulmasını istemişlerdir. Milli kalkınmanın ve toplumun ihtiyaçlarını karşılayabilecek yeni işletmelerini kurulması için finansal destek yanında tüm yönetsel koşulları karşılayabilecek yeni bir örgütsel modele ihtiyaç vardır. $\mathrm{Bu}$ kapsamda, dönemin koşullarına bağlı olarak ortaya çıkan örgütsel yapı "banka merkezli işletme grubudur". Model güçlü bir stratejik bilincin eseridir. Fonksiyonel geçmişlerinde verdikleri karar ve uygulamalar sonucu stratejik yönetim yeteneğini kazanmış olan yönetici kadro kongrede alınan 


\section{Muzaffer AYDEMiR}

kararlar doğrultusunda özgün örgütsel yapılar kurmuşlardır. Banka merkezli işletme grubu, aynı örgütsel yapı altında birçok soruna çözüm getiren yönetsel bir modeldir.

Modelin ortay çıkışını anlayabilmek için bize rehber olacak yönetim yaklaşımı tarihsel dönüşüm metodolojisidir. Tarihsel dönüşüm metodolojisine göre yeni örgütlerin ortaya çıkışı veya geçirdikleri dönüşüm süreçleri dönemin koşullarına bağlıdır. Birinci İzmir İktisat Kongresi'nin düzenlendiği zaman ve sonrasında ülkenin kurumsal koşullarının tamamı olumsuzdur. Tüm bu olumsuz toplumsal, ekonomik ve yönetsel koşulları ortadan kaldıracak milli kalkınmayı gerçekleştirebilmek için kurulan örgütsel yapı banka merkezli işletme grubu olmuştur. Kongrede alınan kararlar çerçevesinde banka ismi ile kurulan örgütsel yapılar her türlü işletmecilik faaliyetini başarılı bir şekilde yürütmüştür. Kuruluş sözleşme ve kanunlarında yer alan esaslar, örgütsel yapı ve işleyişleri ile diğer özellikleri her iki bankanın da kurulduklarında birer işletme grubu olduğunu göstermektedir. Dönemin koşullarının ve ihtiyaçlarının şekillendirdiği örgütsel yapılar gerçekte bir işletme grubu modelidir. Söz konusu model ileriki dönemlerde kurulacak işletme gruplarına başlangıç olmuştur. Türk işletme tarihi çalışmalarında önemli bir yere sahip banka merkezli işletme grubu modelinin çıkış noktası Birinci İzmir İktisat Kongresi’dir.

Türk işletme tarihi çalışmaları farklı dönemleri kapsayacak şekilde genişletilmelidir. Erken cumhuriyet dönemi ve öncesinde yapılan girişimler ve ortaya çıkan örgütsel yapılar işletme tarihi çalışmaları için ayrıcalıklı bir yere sahiptir. Bahse konu dönem yönetim bilimi yaklaşımları ile incelenmelidir. Yakın tarihlerde ortaya çıkan işletme grubu modelinin kökenleri bu dönemlere dayanmaktadır. Yapılacak yeni çalışmalarda farklı ülkelerdeki benzer modellerin incelenmesi Türk ve dünya işletme tarihi literatürüne önemli katkılarda bulunacaktır. 
Türk İşletme Tarihi ve Yönetim Bilimi Açısından Birinci İzmir İktisat Kongresi:

Banka Merkezli İşletme Gruplarının Oluşumu

\section{Kaynakça}

Akgüç, Öztin (1989) 100 Soruda Türkiye'de Bankacılık, Gerçek Yayınevi, İstanbul.

Amatori, Franco ve Jones Geofrey (2007) "Giriş", Franco Amotori ve Geoffrey Jones (Ed.); Dünya İşletme Tarihi, (Çev. Abdullah Ersoy), Dost Kitapevi Yayınlar, Ankara, ss. 13-23.

Amatori, Franco (2009) "Business History: State of the Art and Controversies, in "Revista de Historia Industrial”, Entreprises et Histoires, 39.1, ss. 17-35.

Apak, Kemaliettin, Aydınelli, Cevdet ve Akın, Mehmet (1952) Türkiye'de Devlet Sanayi ve Maadin İşletmeleri, Selüloz Basımevi, İzmit.

Ateş, Toktamış ve Soyak, Alkan (1999) Cumhuriyet Dönemi İktisadi Yap1 ve Finans Sistemi 1923-1946 Dönemi, Creative Yayıncılık, İstanbul.

Aydemir, Muzaffer, Özkaleli Murat ve Katırcıoğlu, Salih (2012) "The Roots of Holdings through State: Evidence from Turkish Industry and Maadin Bank in Turkey", Actual Problems of Economics, 136.11, ss. 250-259.

Aydemir, Muzaffer (2019a) Türkiye'de Üst Yönetim Ekipleri, Altınbaş Üniversitesi Yayınları, Ankara.

Aydemir, Muzaffer (2019b) “Turkey’s Pioneering Model Business Group: İş Bankası (Business Bank)", Saripek Doğa, Yenihan Bora ve Franca Valentin, (Ed.): Critical Review of Social Sciences Contemporary Issues, Frontpage Publications, London, ss. 48-64.

Boratav, Korkut (1988) Türkiye İktisat Tarihi 19081985, Gerçek Yayınevi, İstanbul.

Chung, Chi-Nien (2001). "Markets, Culture and Institutions: the Emergence of Large Business Groups in Taiwan, 1950's-1970's", Journal of Management Studies, 38.5, ss. 719-745.

Durmuş, Savaş ve Aydemir Kemal (2016) "Atatürk Dönemi Türkiye Ekonomisi (1923-1938)”, Kafkas Üniversitesi İktisadi ve İdari Bilimler Fakültesi Dergisi, 7.12, ss. 155-167.

Georgeon, François (2006) Osmanl1-Türk Modernleşmesi 1900-1930 Seçilmiş Makaleler, (Çev. Ali Berktay), Yapı Kredi Yayınları, İstanbul.

Ghemawat, Pankaj ve Khanna, Tarun (1998) “The Nature of Diversified Business Groups: A Research Design and Two Case Studies', The Journal of Industrial Economic", 46.1, ss. 35-61.

Gottschalk, Petter (2007) CIO and Corporate Strategic Management: Changing Role of CIO to CEO, Idea Group Publishing, Hershey.
İnan, Afet (1989) İzmir İktisat Kongresi 17 Şubat-4 Mart 1923, Türk Tarih Kurumu Basımevi, Ankara.

Kahraman, Serpil ve Şişmanoğlu Gizem (2019) “Atatürk Dönemi İktisadi Devletçi Sanayileşme Politikaları”, Iğdır Üniversitesi Sosyal Bilimler Derdergisi, 17, ss. 627-656.

Kandemir, Ahmet (2002) Dünyada ve Türkiye'de Kalkınma Bankacılığı ve Kalkınmanın Finansmanı, Türkiye Kalkınma Bankası Yayın No 12, Ankara.

Kazgan, Haydar, vd. (1999) Osmanlıdan Günümüze Türk Finans Tarihi Cilt II, Creatif Yayıncılık, İstanbul.

Keçetep, İlker (2016) Türkiye'de İktisat Biliminin Doğuşu, Uluslararası Yönetim İktisat ve İşletme Dergisi, ICAFR 16 Özel Sayısı, ss. 823-834.

Keyder, Çağlar (1998) 1923-1932 Dönemi Bankalar, 75 Yılda Paranın Serüveni, Türkiye İş Bankası Kültür Yayınları, İstanbul.

Khanna, Tarun (2000) "Business Groups and Social Welfare in Emerging Markets: Existing Evidence and Unanswered Questions", European Economic Review, 44, ss. 748-761.

Khanna, Tarun ve Palepu, Krishna (2000) "Is Group Affiliation Profitable in Emerging Markets? An Analysis of Diversified Indian Business Groups", The Journal of Finance, 2000, 55.2, ss.867-891.

Khanna, Tarun ve Rivkin, Jan (2001) "Estimating the Performance of Business Groups in Emerging Markets", Strategic Management Journal, 2001, 22.1, ss.45-74.

Khanna, Tarun ve Yafeh, Yishay (2007) "Business Groups in Emerging Markets: Paragons or Parasites", Journal of Economic Literature, XLV, ss. 331-372.

Kocabaşoğlu, Uygur, Sak Güven, Sönmez Sinan, vd. (2001) Türkiye İş Bankası Tarihi, Acar Matbaası, İstanbul.

Koç, Ceyhan (2010) "İzmir İktisat Kongresi'nin Türk Ekonomisinin Oluşumuna Etkileri". Atatürk Dergisi 3, ss. 145-167.

Koçtürk, Murat ve Gölalan Meryem (2010) “19231950 Türkiye Ekonomisinin Yapısal Analizi”, Üçüncü Sektör Kooperatifçilik, 45.2, ss. 48-65.

Korum, Uğur (1982) "1923-1929 Döneminde Türkiye'de İmalat Sanayi ve Sanayi Politikaları" [Bildiri], Atatürk Dönemi Ekonomi Politikası ve Türkiye'nin Ekonomik Gelişmesi Semineri, AÜ. SBF Basın ve Yayın Yüksek Okulu BasımeviNo:513, Ankara, ss. 63-78. 


\section{Muzaffer AYDEMIR}

Köksal, Bilge ve İlkin Rasih (1973) Türkiye'de İktisadi Politikanın Gelişmesi (1923-1973), Binbirdirek Matbaası, Ankara.

Lazonick, William (2007) "Yenilikçi İşletmeyi Anlamak: İktisat Kuramı ve İşletme Tarihinin Bütünleştirilmesine Doğru", FrancoAmotori ve GeoffreyJones (Ed.); Dünya İşletme Tarihi, (Çev. Abdullah Ersoy), Dost Kitapevi Yayınlar, Ankara, ss. $78-101$.

Ökçün, Gündüz (1971) Osmanlı Sanayi 1913, 1915 Yılları Sanayi İstatistiki, Sevinç Matbaası, Ankara.

Özçelik, Özer ve Tuncer Güner (2007) “Atatürk Dönemi Ekonomi Politikaları" Afyon Kocatepe Üniversitesi Sosyal Bilimler Dergisi, 9.1, ss. 253266.

Parasız, İlker (1998) Türkiye'de Bankacılığın Tarihsel Gelişimi, 75 Yılda Paranın Serüveni, Türkiye İş Bankası Kültür Yayınları, İstanbul.

Pıçak, Murat, Süloğlu Duygu ve Eker Abdullah (2017) Cumhuriyet'in İlk Yıllarında Türkiye İş Bankası'nın Kuruluşu ve Ekonomiye Etkisi, (Ed. Koç Selçuk, Genç Sema, Çolak Kerem), Dünden Bugüne Ekonomi Yazıları, ss. 140-162.

Pozzi, Daniele (2014) An Elastic Managerial Revolution: Family, Managers and Multidivisional Organization at Pirelli (1943-56), Business History, 56.5, ss. 765-788.

Recai, Mehmet (1934) Banka, Arkadaş Matbaası, İstanbul.

Serin, Necdet (1983) Türkiye’nin Sanayileşmesi, Sevinç Matbaası, Ankara.
Sivramkrishna, Sashi (2014) "From Merchant to Merchant-Ruler: A Structure-ConductPerformance Perspective of the East India Company's History, 1600-1765", Business History, 56.5, ss. 789-815.

Tezel, Yahya (2015) Cumhuriyet Döneminin İktisadi Tarihi (1923-1950), Yaylacık Matbaacılı, İstanbul.

Tezer, Öcal (1973) Türk Banka Sistemi, Emel Matbaacilık, Ankara.

Tuna, Serkan (2009) Dünya Ekonomik Krizine Bir Cevap mı? Türkiye'de Devlet İşletmeciliği ve Sümerbank (1932-1939), Derlem Yayınları, İstanbul.

Türk, İsmail (1970) Niçin ve Nasıl Sanayileşme, Türkiye'nin Sanayileşmesi Sorunu Semineri, Ayyıldız Matbaası, Ankara.

Türkdoğan, Orhan (1981) Sanayi Sosyolojisi Türkiye'nin Sanayileşmesi Dün Bugün Yarın, Töre Devlet Yayınevi, Ankara

Türkiye İş Bankası Esas Mukavelesi (1946) Kenan Matbaası, İstanbul.

Yaşa, Memduh (1980) Cumhuriyet Dönemi Türkiye Ekonomisi, Akbank Kültür Yayınları, Apa Ofset Basımevi, İstanbul.

Yaşer, Yaşar (1973) Türkiye'de Toplumsak ve Ekonomik Gelişmenin 50 Yılı, Başbakanlık Devlet İstatistik Enstitüsü Matbaası, Ankara.

Zarakolu, Avni (1974) Cumhuriyetin 50. Yılında Memleketimizde Bankacılık, Ayyıldız Matbaası, Ankara. 